\title{
Penyuluhan peningkatan ekonomi masyarakat melalui pengembangan potensi desa wisata di Desa Petalongan Kabupaten Indragiri Hulu
}

\author{
Yasir*, Muhammad Firdaus, Rusmadi Awza, \& Ismandianto \\ Fakultas Ilmu Sosial dan Ilmu Politik, Universitas Riau \\ *yasir@lecturer.unri.ac.id
}

\begin{abstract}
Abstrak. Desa petalongan adalah salah satu desa yang berada di Kecamatan Pasir Penyu Kabupaten Indragiri Hulu yang masih tertinggal. Desa ini memiliki sungai, danau, dan tradisi budaya untuk potensi pengembangan ekonomi atau wisata. Masyarakat masih belum menyadari pentingnya pengelolaan ekosistem ini. Oleh karena itu, tujuan kegiatan pengabdian ini adalah untuk mengubah perilaku masyarakat dalam mengelola dan memanfaatkan alam, tradisi dan budaya untuk meningkatkan ekonomi masyarakat melalui pengembangan wisata. Sasaran kegiatan pengabdian ini adalah pengelola Badan Usaha Milik Desa (Bumdes) dan Ibu-ibu Pemberdayaan Kesejahteraan Keluarga (PKK). Metode pengabdian yang dilakukan dimulai dari pemetaan sosial ekonomi masyarakat, penyuluhan, FGD, dan pendampingan. Kegiatan pengabdian kepada masyarakat ini telah memetakan potensi ekonomi desa dengan berbasis danau. Penyuluhan dan FGD yang dilakukan mengenai masalah yang ada di Desa Petalongan telah memberi kontribusi dalam meningkatkan kesadaran masyarakat. Kegiatan penyuluhan difokuskan pada pemanfaatan danau untuk pembudidayaaan ikan lele dan ikan nila. Selain itu pelatihan sadar wisata dan UMKM perlu segera dilakukan agar dapat meningkatkan pemahaman, sikap dan kemampuan masyarakat dalam memanfaatkan kekayaan sumber daya alam yang ada di desa ini. Penyuluhan ini berdampak positif sehingga masyarakat ingin segera untuk membudidayakan ikan dan memanfaatkan danau untuk wisata dalam meningkatkan pendapatan ekonomi masyarakat.
\end{abstract}

Kata kunci: Pemberdayaan masyarakat, penyuluhan, budidaya ikan, wisata terpadu, desa wisata

\begin{abstract}
Petalongan Village is one of the villages in Pasir Penyu District, Indragiri Hulu Regency, which is still left behind. This village has rivers, lakes, and cultural traditions for economic or tourism development. People still do not realize the importance of managing this ecosystem. Therefore, the purpose of this service activity is to change people's behavior in managing and utilizing nature, traditions and culture to improve the community's economy. The targets of this activity are the managers of Village-Owned Enterprises and Women Empowerment of Family Welfare. The service methods carried out started from the socio-economic mapping, counseling, FGD, and mentoring. This community service activity has mapped the economic potential of the village on a lake-based basis. Counseling and FGDs regarding problems in Petalongan Village have contributed to increasing public awareness. Extension activities focused on using the lake for the cultivation of catfish and tilapia. Besides that, training on tourism awareness and UMKM needs to be carried out immediately in order to increase understanding, attitudes and the ability of the community in utilizing the wealth of natural resources in this village. This counseling has a positive impact so that people want to immediately cultivate fish and use the lake for tourism to increase the community's economic income.
\end{abstract}

Keywords: community empowerment, counseling, fish farming, integrated tourism, tourism village

To cite this article: Yasir., M. Firdaus., R. Awza, \& Ismandianto. 2020. Penyuluhan peningkatan ekonomi masyarakat melalui pengembangan potensi desa wisata di Desa Petalongan Kabupaten Indragiri Hulu. Unri Conference Series: Community Engagement 2: 159-168. https://doi.org/10.31258/unricsce.2.159-168

(C) 2020 Authors

Peer-review under responsibility of the organizing committee of Seminar Nasional Pemberdayaan Masyarakat 2020 


\section{PENDAHULUAN}

Pembangunan sektor pariwisata semakin penting sejalan dengan perkembangan struktur perekonomian Indonesia yang makin mengarah ke sektor jasa (Bagindo, Sanim, \& Saptono, 2016). Pembangunan perekonomian daerah saat ini tidak hanya fokus di daerah perkotaan, justru di daerah pedesaan kini lebih memiliki potensi untuk dikembangkannya. Saat ini pengembangan desa wisata merupakan bagian dari prioritas pembangunan. Pengembangan pariwisata bertujuan untuk memfokuskan kembali, merencanakan dan menerapkan kebijakan yang mendorong pengembangan sumber daya alam untuk memberi manfaat bagi masyarakat adat dan pemangku kepentingan lainnya yang mencakup pemerintah, industri, masyarakat dan para pengunjung itu sendiri. Kebijakan pembangunan wisata seperti ini membutuhkan partisipasi aktif dari masyarakat (Yasir, Nurjanah, Salam, \& Yohana, 2019).

Sejalan dengan ini, pembangunan desa memiliki peran penting dalam meningkatkan kesejahteraan penduduk lokal, karena dukungan penduduk setempat ini sangat penting bagi industri pariwisata. Tantangan untuk pembangunan masyarakat dan pengembangan daya tarik wisata adalah besarnya potensi wisata yang dimiliki derah namun kemampuan masyarakat dalam perencanaan dan pengembangan sangat terbatas padahal memiliki manfaat besar kepada masyarakat (Noor \& Nala, 2020). Masyarakat menjadi pemangku kepentingan yang paling utama dalam proses pencapaian pembangunan berkelanjutan di bidang pariwisata (Lundberg, 2017). Selain itu, pengembangan pariwisata juga harus berbasis budaya dan kearifan lokal dengan didukung dengan pelestarian dan pembangunan lingkungan berkelanjutan (Bakti, Sumartias, Damayanti, \& Nugraha, 2018). Oleh karenanya, pembangunan ekonomi dan pariwisata di daerah sebagai salah satu sektor pembangunan tidak dapat dilepaskan dengan pembangunan masyakat dan pembangunan fasilitas pendukungnya.

Pembangunan desa memiliki peran penting dalam memelihara warisan budaya, kearifan lokal dan kelestarian alam. Hal ini bisa dilihat penelitian terkait pariwisata budaya dan industri kreatif yang menjadi tren baru bagi wisatawan (Liu, 2018). Pembangunan desa dasarnya berupaya mendorong masyarakat dan pemangku kepentingan untuk saling mendukung. Masyarakat desa dilibatkan tidak hanya sekedar sebagai objek tapi juga sebagai subjek pembangunan, karena pembangunan bersifat sistemik dan terpadu. Terkait dengan pembanguna pariwisata terpadu, peran masyarakat secara aktif dalam kegiatan pariwisata dapat dilaksanakan secara langsung maupun tidak, baik secara perseorangan maupun secara bersama-sama (Ridlwan, Muchsin, \& Hayat, 2017). Kesadaran dan partisipasi warga terhadap pembangunan pariwisata ini sangat penting karena berdampak langsung terhadap pembangunannya.

Kesadaran masyarakat dalam meningkatkan produktivitas dan potensi daerah merupakan salah satu faktor penting yang mempengarui keberhasilan program memberdayakan masyarakat (Bahri \& Prasetyo, 2020). Lingkungan di pedesaan merupakan daya tarik wisata yang unik yang perlu disadari dan dikembangkan masyarakat, yaitu dengan memanfaatkan kekhasan daerah melalui keindahan alam dan budaya masyarakatnya. Wisata pedesaan dapat memiliki bentuk organisasi berupa desa yang dikelola menjadi desa wisata yang seluruh atraksi, amenitas, dan kelembagaannya berasal dari inisiatif dan keinginan warga sendiri. Hampir selalu dapat dikatakan bahwa wisata pedesaan adalah bentuk dari wisata untuk kegiatan mengenang masa lalu (memorial). Meskipun dalam kenyataannya, wisata pedesaan cenderung mengalihkan kegiatan wisatawan dari rutinitas wisatawan sehari-hari, atau semacam menenangkan diri dari hiruk-pikuk kehidupan perkotaan. Hal ini lah yang menarik bagi desa-desa di Kecamatan Pasir Penyu Kabupaten Indragiri Hulu sebagai destinasi wisata untuk dikembangkan sebagai daya tarik dan solusi untuk meningkatkan ekonomi masyarakat secara terpadu melalui pembangunan kawasan wisata terpadu.

Salah satu persoalan yang mendasar dalam pembangunan dan peningkatan ekonomi masyarakat adalah rendahnya pengetahuan dan keahlian dalam mengelola potensi ekonomi dan wisata yang ada. Untuk mengoptimalkan potensi sumber daya alam dan sumber daya manausia memerlukan sentuhan manajemen profesional agar potensi ini dapat dimanfaatkan secara optimal. Pemberdayaan berbasis community-based tourism (CBT) mengacu pada usaha sektor pembangunan pariwisata yang didominasi oleh usaha kecil yang menyediakan barang dan jasa kepada wisatawan (Noor \& Nala, 2020). CBT adalah salah satu bentuk pembangunan pariwisata yang bertujuan untuk pemberdayaan masyarakat dalam rangka pengelolaan perkembangan pariwisata dan mengakomodasi aspirasi dan kebutuhan masyarakat yang menyangkut kesejahteraan mereka dalam konteks pembangunan sosial ekonomi masyarakat berbasis lingkungan yang berkelanjutan. Pariwisata berbasis CBT ini memperkuat masyarakat lokal untuk menentukan dan menjaga masa depan sosial ekonomi yang bertujuan menjaga tradisi lokal, sumber daya adalam dan budaya lokal. 
Pembinaan melalui penyuluhan maupun pelatihan terhadap masyarakat diharapkan dapat membantu masyarakat memahami pentingnya mengelola sumberdaya alam untuk meningkatkan pendapatan ekonomi masyarakat melalui kegiatan industri yang terkait dengan ini. Tantangannya adalah masyarakat Desa Petalongan belum sepenuhnya menyadari potensi sumber daya alam yang dimiliki untuk meningkatkan taraf ekonomi masyarakat. Padahal, pemerintah derah Indragiri Hulu memiliki beberapa misi untuk mengembangkan kesejahteraan masyarakat. Di antara misinya yaitu upaya untuk memelihara nilai luhur budaya daerah Kabupaten Indragiri Hulu yang berpijak pada nilai - nilai agama guna menyaring pengaruh budaya lain untuk mempertahankan identitas dan integritas Kabupaten Indragiri Hulu. Selain itu, memberdayakan kekuatan ekonomi yang berbasis kerakyatan melalui Peningkatan kualitas dan kapasitas manajemen, permodalan, produksi dan peningkatan kemampuan dalam mengakses sumber-sumber bahan baku, teknologi pasar dan faktor lainnya.

Wilayah Desa Petalongan secara administratif berada di Kecamatan Pasir Penyu Indragiri Hulu. Desa Petalongan memiliki jarak tempuh 156 kilometer dari kota Provinsi Riau, Pekanbaru. Sementara jarak tempuh dari Desa Petalongan ke kota kabupaten yaitu 35 kilometer. Jumlah penduduk Desa Petalongan yaitu 1063 orang yang terdiri dari 548 orang laki-laki dan 515 perempuan dengan $317 \mathrm{KK}$. Masyarakat seratus persen muslim. Masyarakat yang berumur 18-56 tahun memiliki tingkat pendidikan rendah sekali, tidak sekolah atau tidak tamat SD mencapai mencapai 137 orang, 266 orang hanya sampai menamatkan SD. Desa ini berada dalam kategori desa tertinggal. Mata pencaharian penduduknya adalah petani sawit yang mayoritas sebagai buruh tani atau karyawan perkebunan dan wiraswasta (data Profil Desa Petalongan tahun 2018).

Desa Petalongan memiliki luas wilayah 2.050 hektar, yang terbelah menjadi dua wilayah karena dipisahkan oleh Sungai Indragiri. Sepanjang pinggiran sungai banyak ditemukan penambang pasir dan emas, sebagai mata pencaharian sebagian masyarakat. Kondisi ini tentu memperparah ekosistem sungai. Sebagian besar wilayah ada di seberang pusat pemerintahan Desa Petalongan. Namun aksesnya belum bisa dijangkau dengan transportasi darat secara langsung, kecuali dengan penyebrangan melalui "Kompang". Padahal wilayah di seberang ini merupakan wilayah yang berpotensi besar untuk persawahan, perkebunan, perikanan berbasis danau. Danau ini memiliki panjang dua kilometer dan rata-rata lebar antara 50 - 100 meter. Danau ini menjadi tempat favorit memancing masyakat setempat maupun dari luar daerah. Danau ini sangat berpotensi menjadi tempat budidaya ikan, jika dikelola dengan baik dapat dikembangkan sebagai tempat tambak ikan, sebagai tempat event-event perlombanan seperti memancing, pacu sampan, dan kegiatan lainnya. Sedangkan daerah di pinggiran danau sebagian masih ada yang asri dengan tanaman hutannya, namun sebagian yang lain berupa kebun sawit dan lahan menganggur tanah cetak untuk sawah.

Danau ini dapat berpotensi memberikan banyak kemanfaatan bila dikelola dengan baik bahkan menjadi pemasukan ekonomi masyarakat. Faktanya hingga saat ini danau tersebut tidak dirawat dan belum dikelola dengan baik. Memang ada beberapa kendala terkait pengembangan derah ini seperti: akses yang sulit, jauh dari pemukiman penduduk, dan minimnya pengetahuan dan keahlian masyarakat untuk mengelola budidaya ikan. Budidaya ikan keramba atau perternakan ikan di danau ini punya potensi besar dikembangkan. Tidak dari sisi perikanan saja, tapi dari sisi pertanian dan perkebunan bahkan pariwisata sangat berpoteni baik jika dikelola secara terpadu. Danau tersebut merupakan aset atau modal yang utama sebagai kekayaan alam, yang perlu dirawat dan dilestarikan melalui metode pengembangan kawasan wisata terpadu.

Permasalahan utama Desa Petalongan adalah masyarakat khususnya Bumdes belum memanfaatkan danau/tasik untuk budidaya ikan maupun untuk pengembangan potensi yang lain seperti seperti kawasan wisata. Kesadaran masyarakat untuk yang rendah membuat banyak pottensi ini menganggur dan terbengkalai. Adapun yang menjadi tujuan dilaksanakannya pengabdian ini adalah memberikan pengetahuan dan kemampuan membudidayakan ikan di dalam keramba kepada masyarakat. Selain itu, tujuan kegiatan pengabdian ini adalah untuk memberikan penyuluhan kepada masyarakat tentang pentingnya pengelolaan dan pemanfaatan alam, tradisi dan budaya untuk dapat meningkatkan ekonomi masyarakat melalui usaha mikro kecil dan menengah (UMKM). UMKM jelas mempunyai peran yang sangat besar dalam memajukan perekonomian Indonesia dimana UMKM berkontribusi besar dalam penyerapan tenaga kerja dan mengurangi pengangguran (Bahri \& Prasetyo, 2020). Pengabdian ini juga ingin mengubah pandangan masyarakat agar memiliki kemampuan dalam mengembangkan potensi desa untuk ekowisata, agrowisata dan wisata budaya yang dapat dikelola secara terpadu. Selain itu melalui pengabdian ini diharapkan masyarakat dapat menjaga dan memanfaatkan nilai-nilai kearifan lokal dalam menjaga tradisi dan lingkungan sebagai pendukung daya tarik pengembangan wisata terpadu yang dapat berkontribusi dalam pembangunan desa berkelanjutan. Sasaran 
kegiatan penyuluhan ini adalah kelompok masyarakat yang tinggal di Desa Petalongan, khususnya aparat pemerintahan desa, Ibu-ibu PKK dan pengelola BUMDes.

\section{METODE PENERAPAN}

Pembangunan desa dan peningkatan ekonomi masyarakat sangat membutuhkan pendampingan atau pemberdayaan masyarakat. Pemberdayaan dengan Model Community Based Tourism (CBT) menarik digunakan. Model ini merupakan strategi perencanaan pengembangan kepariwisataan yang berorientasi pada pemberdayaan masyarakat setempat sebagai subjek pembangunan (Ridlwan et al., 2017). Pengembangan desa binaan sangat strategis bukan hanya untuk perguruan tinggi sebagai pendamping, tetapi juga merupakan kepentingan daerah bahkan nasional, yang diharapkan akan berdampak positif dalam meningkatkan kesejahteraan masyarakat. Pengembangan desa binaan dalam kegiatan ini memperhatikan hal-hal penting berikut ini, yaitu: (1) dikelola melalui pengorganisasian yang dapat melibatkan semua unsur dan institusi mulai dari tingkat keluarga, RT, RW, Desa, Kecamatan, dan Kabupaten. (2) dijalankan secara mandiri dan terusmenerus dikembangkan sesuai dengan tuntutan dan kebutuhan masyarakat, (3) program disusun melalui tahapan perencanaan, pelaksanaan, monitor dan evaluasi, serta adanya keberkelanjutan, (4) dikembangkan prinsip-prinsip kemitraan dengan stakeholders, dan (5) diarahkan untuk menjadi lembaga yang mampu memperkuat struktur sosial masyarakat desa.

Pengabdian ini dilaksanakan dari bulan Juli s/d November 2020. Metode pembinaan dilakukan dengan pemetaan sossial ekonomi masyarakat, focus group discussion (FGD), penyuluhan, dan pendampingan. Dalam hal ini, metode penerapan pengabdian kepada masyarakat di Desa Petalongan Kecamatan Pasir Penyu Kabupaten Indragiri Hulu, melalui program desa binaan. Program pembinaan desa dilaksanakan menggunakan rangkaian tahapan yang disusun secara sistematis, yaitu Persiapan, Pelaksanaan, Evaluasi dan Pelaporan.

a. Tahap Persiapan, yaitu 1) survei lapangan; 2) membentuk kerja sama dengan aparat desa setempat, pengelola Badan Usaha Milik Desa (Bumdes); 3) Membentuk kerjasama dengan pengisi materi (dari pihak akademisi-Universitas/Dosen dan juga dari pihak dinas pariwisata Kabupaten Indragiri Hulu). 4) Menyiapkan materi penyuluhan yang menyesuaikan pada kebutuhan masyarakat. Saat dilakukan survei masyarakat banyak mengandalkan mata pencaharian penambangan pasir dan emas yang tidak pendapatnnya tidak seberapa padahal potensi yang dimiliki desa adalah danau. Sehingga kebutuhan masyarakat adalah minimnya pengetahuan dan keahlian dalam membudidayakan ikan keramba dan minimnya keahlian dalam pengelolaan Usaha Mikro Kecil dan Menengah.

b. Pelaksanaan, yaitu: 1) Memberikan penyuluhan kepada masyarakat Desa Petalongan dan khususnya Pengelola Bumdes dalam pengelolaan dan pengembangan budidaya ikan lele dan nila di Danau Petalongan; 2) Memberikan sosialisasi pentingnya pengelolaan dan pengembangan Usaha Mikro Kecil dan Mengengah (UMKM); 3) Melakukan Focus Group Discussion (FGD) mengenai pentingnya mengidentifikasi potensi desa dalam mengembangkan ekowisata dan kawasan wisata terpadu

c. Evaluasi; yaitu pengabidan ini dievaluasi dari proses awal persiapan hingga pelaksanaan dan terkait dengan perubahan perilaku masyarakat. Tahapan ini juga melakukan tidakan lebih lanjut dengan membuat rekomendasi tahapan selanjutnya. Selain itu memberikan rekomendasi kepada pembuat kebijakan. Rekomendasi dalam bentuk model pemberdayaan komunitas masyarakat dalam meningkatkan ekowisata danau dan berbasis agrowisata. Selain itu memberikan rekomendasi kepada pemerintah setempat, terkait kebutuhan mendesak dalam menunjang program pembinaan masyarakat secara berkelanjutan yaitu infrastruktur dan pembinaan yang intensif.

Ukuran ketercapaian pengabdian kepada masyarakat melalui sosialisasi program desa binaan ini adalah adanya perubahan dari sisi pengetahuan, sikap dan perilaku masyarakat. Keberhasilan sosialisasi terlihat dari pemanfaatan potensi desa dalam mengembangkan budidaya ikan dan membuat keramba ikan di Danau Petalongan. Mereka tidak sekedar tahu bagaimana mengelola danau sebagai tempat budidaya ikan, namun mereka memiliki sikap yang baik terhadap potensi ekonomi desa dan mengembangkan destinasi wisata pada danau yang ada.

\section{HASIL DAN KETERCAPAIAN}

Dalam kegiatan pengabdian kepada masyarakat, partisipasi masyarakat sangat berpengaruh terhadap tercapainya program kegiatan. Partisipasi masyarakat penting untuk menjamin efisiensi dan keberlanjutan program karena membantu mengidentifikasi strategi dan teknik yang lebih tepat-guna, serta meringankan beban pemerintah, baik dari sisi dana, tenaga, maupun material (Qomar et al., 2019). Komunikasi dengan 
memberdayaan masyarakat agar masyarakat dapat berpartisipasi aktif juga sangat penting untuk mewujudkan pengelolaan sumber daya alam yang efektif dan berkelanjutan (Yasir, Nurjanah, \& Yesicha, 2017). Berikut digambarkan pelaksanaan pengabdian kepada masyarakat melalui Program Desa Binaan dengan melibatkan masyarakat dan pengelola Bumdes Desa Petalongan Kecamatan Pasir Penyu.

\section{a. Pemetaan Potensi Desa dan Danau Petalongan}

Pendekatan pemberdayaan masyarakat (community-based tourism) sangat penting dilakukan karena dapat meningkatkan kapasitas masyarakat agar secara mandiri mengidentifikasi masalah, potensi, dan kebutuhan masyarakat, melakukan kajian dampak sosial, ekonomi, dan lingkungan deri pengembangan daerah wisata dan marketing untuk mempromosikan derah wisata guna menarik wisatawan (Noor \& Nala, 2020). Oleh karena itu Tim berusaha untuk membantu masyarakat dalam memetakan potensi ekonomi dan wisata desa. Secara umum Desa Petalongan memiliki luas wisalayah 2.050 hektar. Sebagian besar wilayah ada di seberang pusat pemerintahan Desa Petalongan. Desa Petalongan ini wilayahnya terpisah oleh sungan Indragiri atau Batang Kuantan, bahkan lebih dari 4/5 luas wilayah Desa Petalongan ada di seberang sungai dengan jumlah 100 rumah, sementara 150 lima rumah penduduk mendiami $1 / 5$ wilay ah yang di wialayah ini terdapat kantor kepala desa. Padahal dulunya asal desa atau kampung tua tempat desa ini berada di seberang sungai ini.

Desa ini memiliki danau sebagai bagian anak sungai Indragiri yang airnya tidak dapat lagi mengalir ke sungai induk. Danau ini memiliki panjang dua kilometer dan rata-rata lebar antara 50 - 100 meter.Danau ini menjadi tempat favorit memancing masyakat setempat maupun dari luar daerah. Danau ini sangat berpotensi menjadi tempat budidaya ikan, jika dikelola dengan baik dapat dikembangkan sebagai tempat tambak ikan, sebagai tempat event-event perlombanan seperti memancing, pacu sampan, dan kegiatan lainnya. Sedangkan daerah di pinggiran danau sebagian masih ada yang masih asri dengan tanaman hutannya, namun sebagian besar yang lain berupa kebun sawit dan lahan menganggur tanah cetak untuk sawah.

Danau ini dapat berpotensi memberikan banyak kemanfaatan bila dikelola dengan baik bahkan menjadi pemasukan badan usaha milik desa (Bumdes) dan bagi Pendapatan Asli Daerah (PAD) Kabupaten Indragiri Hulu dari sektor perikanan. Faktanya hingga saat ini danau tersebut tidak dirawat dan belum dikelola dengan baik. Masyarakat sudah pernah memulai mengolah danau tersebut dengan membuat tambak ikan secara swadaya, tapi kurang mendapatkan pembinaan secara berkelanjutan. Disamping itu banyak kendala lain sepeerti: jauhnya lokasi danau, akses yang sulit, jauh dari pemukiman, dan minimnhya pengetahuan dan keahlian mengelola budidaya ikan. Budidaya ikan keramba atau perternakan ikan di danau puya potensi besar tidak dari sisi perikanan, tapi dari sisi pertanian dan wisata yang dikelola secara terpadu. Danau tersebut merupakan aset atau modal yang utama sebagai kekayaan alam, yang perlu dirawat dan dilestarikan melalui metode pengembangan kawasan wisata terpadu.

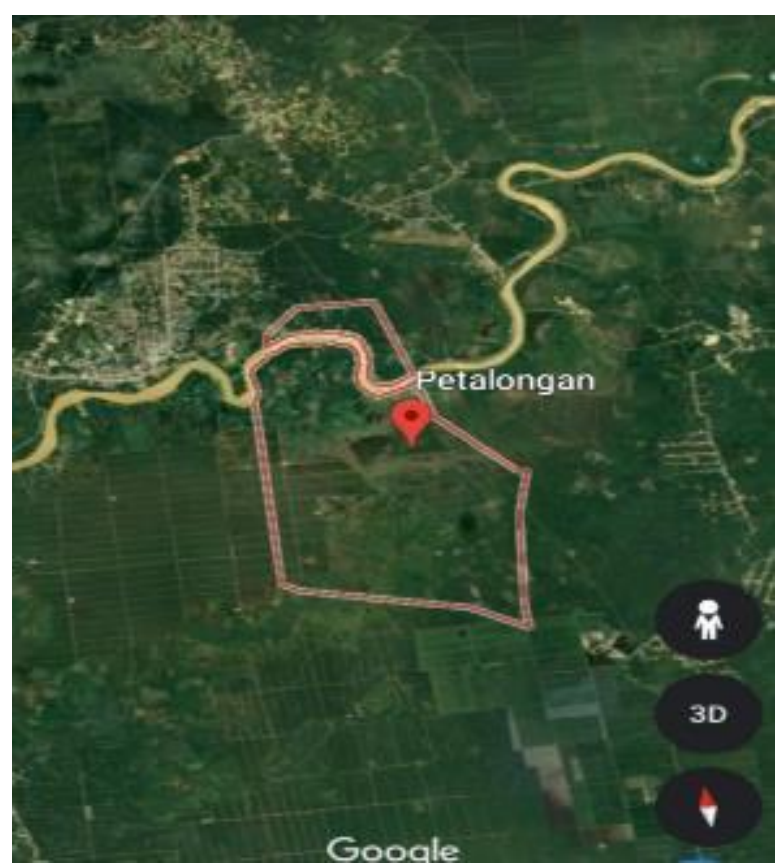

Gambar 1. Peta Desa Petalongan

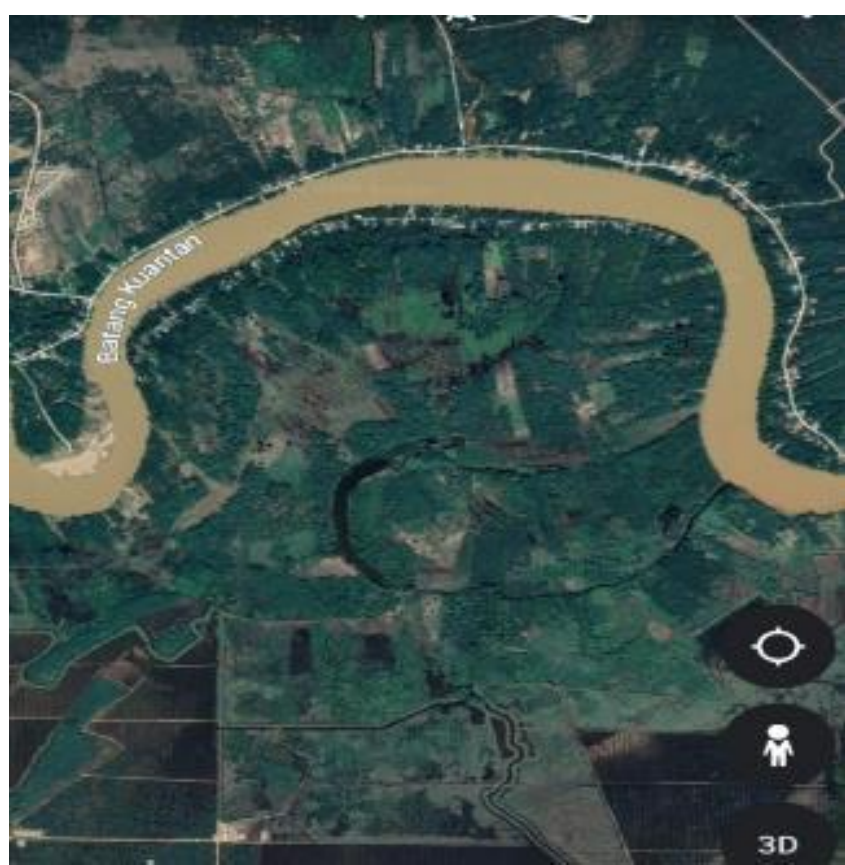

Gambar 2. Peta Lokasi Danau Petalongan 
Hambatan pengembangan potensi ini ada pada sisi sarana prasarana. Jalan akses menuju lokasi danau masih sulit dijangkau, karena harus menyebrangi sungai Indragiri dengan menggunakan "Kompang". Kesadaran masyarakat masih rendah untuk mengelola danau sebagai basis budidaya ikan dan destinasi wisata. Disamping itu masyarakat belum memiliki alternatif untuk meningkatkan pendapatan ekonomi mereka selain hanya mengandalkan kebun sawit. Rendahnya tingkat pendidikan dan keahlian masyarakat dalam mengelola lahan perkebunan/pertanian mereka juga membuat sawit tidak maksimal prouksinya. Selain itu, biaya produksi tinggi karena harus diangkut dengan menyebrangi "Kompang" dan hanya bisa dibawa oleh sepeda motor atau kendaraan yang beroda dua. Padahal masyarakat memiliki alternatif mengelola danau ini sebagai alternatif peningkatan ekonomi. Namun tidak semua masyarakat menyadari akan pentingnya pengelolaan ekosistem tasik yang ada sebagai potensi objek wisata. Padahal jika kawasan ini dikembangkan secara terpadu, daerah ini dapat memiliki nilai ekonomis tinggi. Oleh karena itu, untuk meningkatkan taraf ekonomi masyarakat perlu diadakan penyuluhan dan pelatihan serta pembinaan berkelaanjutan agar masyarakat memiliki kesadaran mengelola sumberdaya alam baik untuk kegiatan budidaya ikan maupun wisata dan masyarakat juga memiliki kemampuan mengelola potensi yang ada.

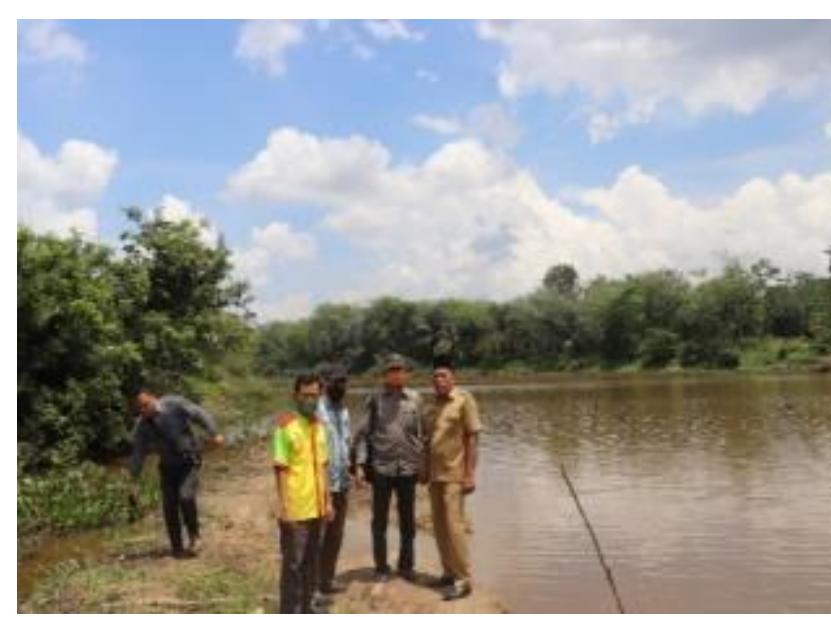

Gambar 3. Tim Melakukan survei ke Danau Petalongan

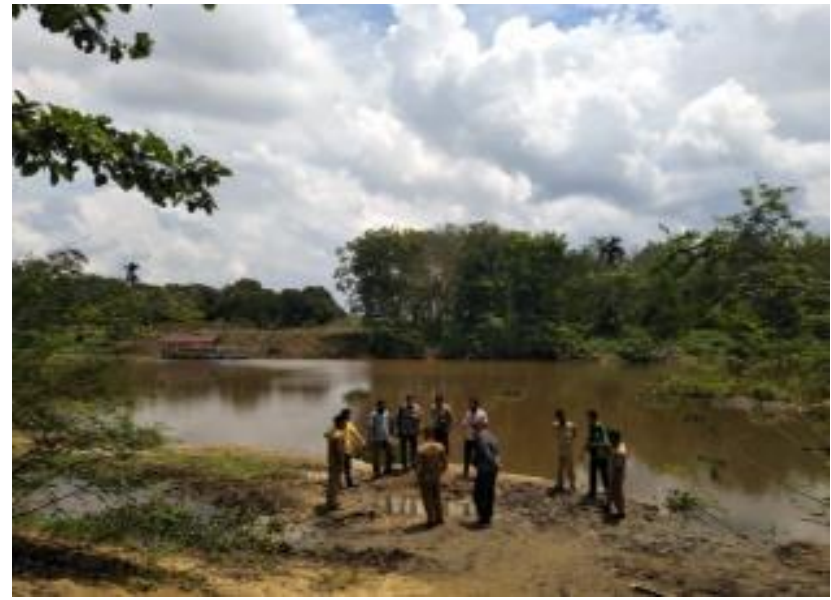

Gambar 4. Berdiskusi dengan Aparatur desa dan Pengelola Bumdes Desa Petalongan

\section{b. Melakukan Penyuluhan Pemanfaatan Potensi Desa dan Danau Petalongan}

Tim pengabdian melakukan kegiatan penyuluhan terkait pentingnya mengelola potensi Desa Petalongan. Kegiatan penyuluhan ini dilkukan pada 24 Agustus 2020. Desa Petalongan memiliki tasik atau danau yang airnya masih jernih dan belum tercemar yang sangat berpotensi untuk dikembangkan untuk budidaya ikan. Sekeliling danau memiliki area hutan yang masih asridan fauna yang sesuai habitatnya juga sangat berpotensi dikembangkan sebagai ekowisata. Perkebunan buah bisa dimanfaatkan sebagai alternatif untuk kegiatan agrowiata, untuk mengantisipasi rendahnya produktivitas hasil kebun sawit. Sawah yang sudah ada cetakannya dapat dikembangkan menjadi sawah alternatif untuk eduwisata masyarakat dan anak sekolah.

Danau ini memiliki potensi untuk pembudidayaan ikan. Ikan yang mudah dibudidayakan dan dipasarkan adalah ikan yang harus dipilih. Oleh karena itu tim menyarankan untuk mengembangkan ikan lele, nila dan ikan patin. Ikan patin memang secara pasar tidak banyak menguntungkan, namun demikian jika diolah menjadi ikan salai dan olahan produk kerupuk kulit ikan, nugget ikan patin dapat lebih menguntungkan. Selain itu, Tim memberikan penyuluhan pentingnya mengembangkan potensi danau dan kawasannya untuk tetap dipelihara, ditanami kembali pinggirannya, dibuatkan dam agar tidak dialiri lagi oleh sungai induk agar dapat dikelola menjadi kawasan wisata terpadu. Kawasan ini memiliki potensi untuk dikembangkan menjadi destinasi wisata, baik untuk memancing, perlombaan memancing, pacu sampan, dan sebagai destinasi agrowisata.

Penyuluhan kepada masyarakat terkait pembangunan ekonomi masyarakat perdesaan merupakanbagian integral dari pembangunan nasional. Pembangunan dengan memaksimalkan potensi sumberdaya alam dan sumberdaya manusia berbasis desa menjadi sangat penting dilakukan. Pembangunan berbasis desa merupakan usaha peningkatan kualitas sumberdaya manusia perdesaan dan masyarakat secara keseluruhan yang dilakukan secara berkelanjutan berlandaskan pada potensi dan kemapuan perdesaan (Zulfida, Fauzi, Rustiadi, \& Syaukat, 
2017). Oleh karena itu, penyuluhan ini diharapkan dapat meningkatkan pengetahuan dan kemampuan masyarakat dalam memanfatkan potensi desa.

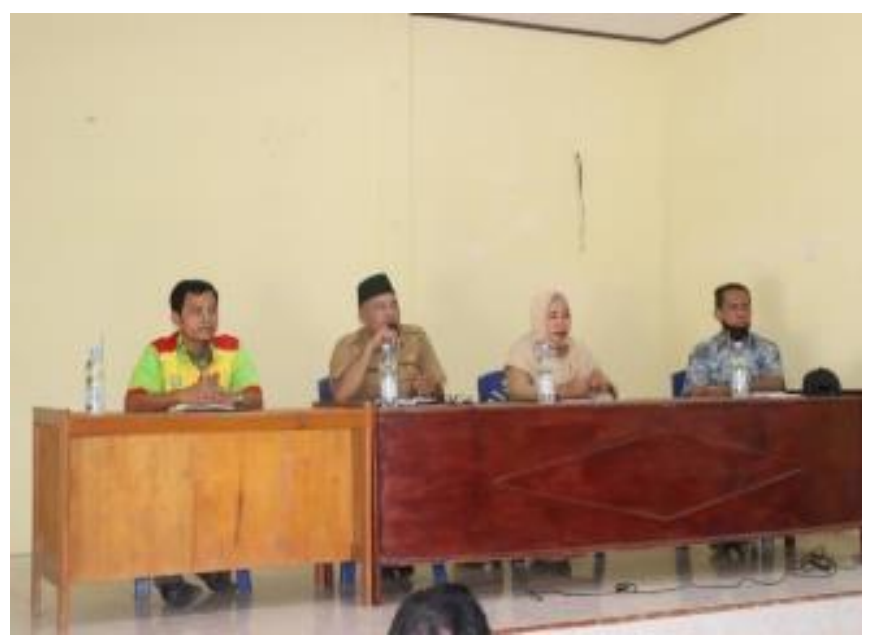

Gambar 5. Kegiatan Penyuluhan

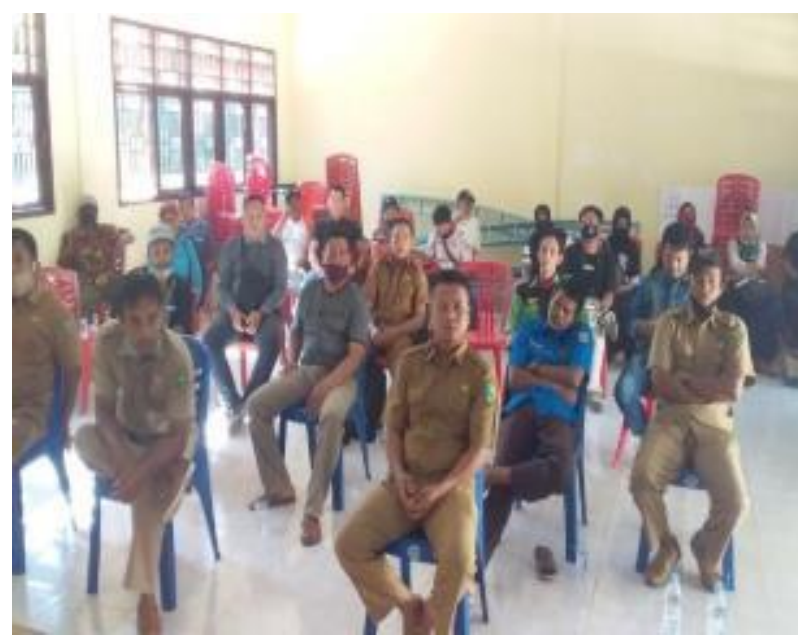

Gambar 6. Kegiatan FGD

\section{c. Melakukan Focus Group Discussion (FGD)untuk Mecari Solusi Pengembangan budidaya Ikan Lele dan Ikan Nila}

Tingginya permintaan pasar untuk kebutuhan ikan terutama ikan lele menjadikan budidaya ikan lele merupakan suatu kegiatan usaha yang memiliki prospek yang baik dan layak untuk dikembangkan ditinjau dari aspek pasar, aspek teknis dan aspek finansial(Mulyadi, Pamukas, Adelina, Lukistyowati, \& Yoswati, 2019). Usaha budidaya lele berpotensi untuk dikembangkan di Desa Petalongan karena tingginya permintaan pasar, tidak hanya di derah sekitar Kecamatan Pasir Penyu. Tapi dapat dipasarkan di derah lain bahkan sampai ke Kabupaten Kuantan Singingi dan Kabupaten Indragiri Hilir. Budidaya lele dapat dikembangkan dengan mudah karena dapat dilakukan pada lahan sempit/pekarangan rumah, tingkat teknologi yang digunakan cukup sederhana sehingga dapat diterapkan oleh petani, sarana dan prasarana pendukung budidaya secara umum mudah didapat atau bisa dimodifikasi, dan nilai tambah produk dapat ditingkatkan melalui teknis budidaya yang dapat diterapkan di tingkat petani. Apalagi potensi danau yang airnya jernih dan lahan yang luas, sangat layak untuk dikembangkan dan terus ditambah tambaknya.

Masyarakat memiliki semangat untuk membudidayakan ikan di danau yang ada didesanya. Adapun ikan yang dipilih untuk dikembangkan adalah ikan nila dan ikan lele karena memiliki prospek pasar yang luas. Pemasangan jaring dan keramba di Danau Petalongan dimulai tepat pada hari Selasa, tanggal 15 September 2020.

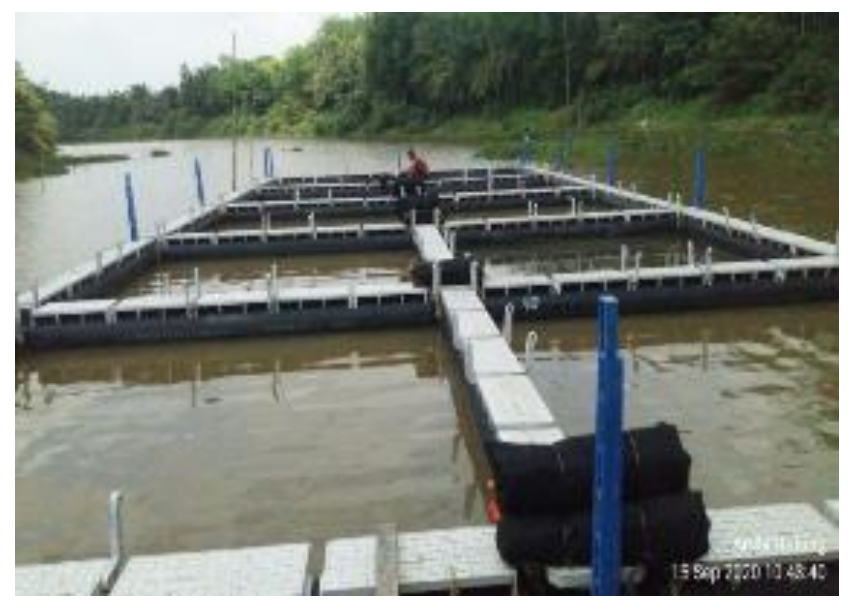

Gambar 7. Tambak Ikan Bumdes

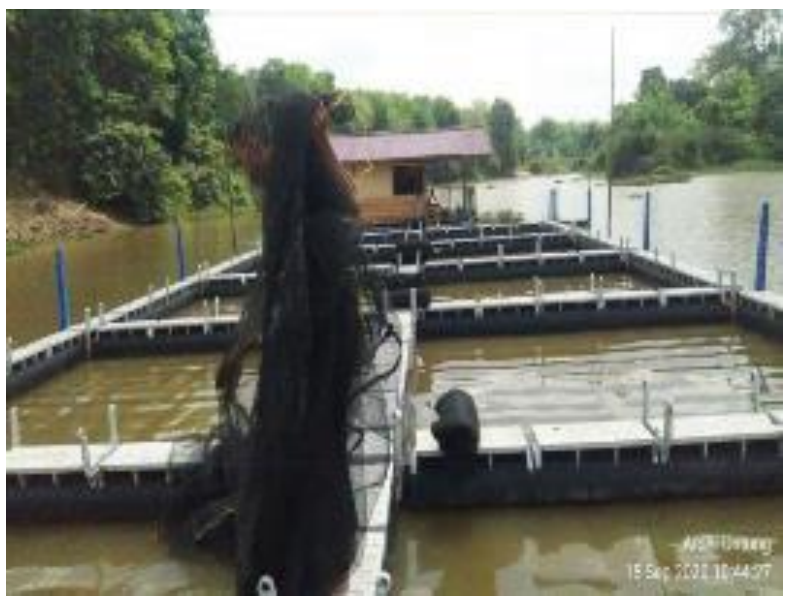

Gambar 8. Kegiatan Pemasangan jaring 
Selama kegiatan FGD, masyarakat banyak mempermasalahkan kondisi danau yang jauh dari keramaian, manajemen pengelolaan dan kemampuan dalam membudidayakan dan memasarkan serta menghitung peluang untung-ruginya. Selain itu, masyarakat banyak mempertanyakan cara mengantisipasi kendala-kendala selama membudidayakan ikan yang kemungkinan ikan dicuri, dimakan predator lain, akses untuk menjangkau ke tengah danau, dan sebagainya. Setelah dilakukan kegiatan FGD, masyarakat terutama Bumdes tertarik mengembangkan budidaya ikan jika ada yang memberikan pembinaan. Tim memberikan solusi akan tetap mendampingi masyarakat untuk jangka panjang, termasuk mendatangkan tim yang ahli terutama dosen yang memiliki latar belakang ilmu budidaya perikanan. Selain itu Tim juga berusaha untuk melakukan koordinasi dengan Dinas terkait untuk membantu keberhasilan para nelayan yang akan membudidayakan ikan ini nantinya.

\section{d. Ketercapaian Pengabdian dan Rekomendasi Pengembangan Desa Petalongan}

Sejalan dengan pemetaan yang dilakukan, penyuluhan dan Focus Group Discussion (FGD), Tim menemukan banyak potensi yang dimiliki desa ini. Rekomendasi kegiatan penyluhan ini, mengantarkan pada kegiatan berikutnya untuk memberikan pelatihan dan pembinaan berkelanjutan. Kegiatan pelatihan dan pembinaan menghadapi kendala akibat meluasnya wabah Covid 19 di Kecamatan Pasir Penyu dan juga di Kota Pekanbaru. Namun demikian Tim tetap melakukan kegiatan pengabdian melalui penggunaan media daring atau online seperti WA dan membagikan materi pelatihan.

Meskipun demikian, rangkaian kegiatan pengabdian ini melalui pemetaan sosial ekonomi masyarakat dan FGD/penyuluhan yang dilakukan telah mendapatkan sambutan dari peserta khusunya pengelola Bumdes dan ibu-ibu PKK. Ketercapaian program ini sudah terlihat dari keberadaan tim yang mendapatkan sambutan baik. Mereka sangat mengharapkan adanya program pelatihan dan pendampingan yang bisa mengubah kehidupan mereka. Mereka menginginkan pelatihan agar mereka memiliki cara, teknik dan metode dalam mengembangkan desa mereka. Peserta juga sangat mengharapkan adanya pelatihan budidaya ikan lele dan nila, karena mereka sudah memiliki rencana dari awal. Oleh karena itu program ini memiliki ketercapaian sangat baik hal ini bisa dilihat dari keinginan masyarakat membudidayakan dan mebuat keramba ikan langsung dipraktikkan. Selain itu, adanya gagasan tim untuk pengembangan destinasi wisata berbasis Danau Petalongan di Desa Petalongan ini, mendapatkan sambutan baik. Selain itu, memang artikel ini hanya fokus pada kegiatan pemetaan dan penyuluhan saja, untuk kegiatan pelatihan dan pendampingan yang berkelanjutan akan dijelaskan pada artikel yang lain.

Intinya kegiatan pengabdian ini telah membuat peserta penyuluhan baik dari sisi pengelola Bumdes dan ibu-ibu Pemberdayaan Kesejahteraan Keluarga (PKK) sikap yang positif terhadap potensi pengembangan ekonomi pedesaan. Melalui sasaran khalayak ini diharapkan mereka mampu mempraktikkan ilmunya da menyebarkan kepada masyarakat umumnya yang ada di desa mereka. Secara bertahap Tim berkesimpulan kegiatan ini telah berhasil hal ini terbukti Bumdes sebagai pengelola budidaya ikan saat ini sudah membuat keramba sebanyak 10 buah di Desa Petalongan yang sebelumnya hanya membiarkan saja danaunya.

Untuk mendukung kegiatan Bumdes ini, Tim pengabdian sudah akan melakukan pembinaan sampai mereka memiliki keahlian dalam mengembangkan budidaya ikan di Danau Petalongan. Bahkan diharapkan kedepan mereka dapat menambah dan memperluas keramba ikan mereka, serta menambah dengan jenis budidaya ikan lain yang memiliki pasar khusus seperti ikan baung atau ikan gurame. Selain itu, dalam tahapan berikutnya tim juga akan melakukan pelatihan lainnya agar Bumdes dapat langsung mengembangkan potensi lain dengan mengembangkan potensi wisata di danau Petalongan. Untuk mendukung ini, Tim merekomendasikan adanya pelatihan UMKM dan sadarwisata untuk segera dilakukan agar peningkatan ekonomi masyarakat mengalami percepatan. Selain itu, Tim merekomendasikan kepada pemerintah daerah Kabupaten Indragiri Hulu untuk membuat atau memperbaiki akses jalan menuju lokasi danau untuk memaksimalkan potensi desa. Karena jelas bahwa pengembangan ekowisata berkelanjutan (sustainability of ecotourism) dipengaruhi oleh beberapa aspek seperti tingkat kebiasaan dan sikap masyarakat terhadap lingkungannya, tingkat dukungan kebijakan pemerintah dalam pengembangan ekowisata, serta tanggungjawab para pihak yang terkait (stakeholders) (Bagindo et al., 2016).

\section{KESIMPULAN}

Rangkaian kegiatan pengabdian kepada masyarakat di Desa Petalongan dari pemetaan potensi desa, penyuluhan dan FGD telah memberi dampak positif bagi pemahaman, sikap dan kemampuan masyarakat dalam memanfaatkan kekayaan sumber daya alam yang ada di desa ini. Masyarakat sudah memulai memiliki kesadaran untuk membudidayakan ikan dan memanfaatkan danau yang ada di derahnya untuk meningkatkan 
pendapatan dan ekonomi masyarakat melalui Bumdes. Mereka juga mulai menyadari pentingnya mengembangkan potensi danau sebagai objek wisata, begitu juga keberadaan lahan kebun dan lahan bekas sawah yang menganggur yang ada di sekeliling danau. Kemampuan masyarakat untuk mengelola potensi desa masih rendah, sehingga perlu dilakukan segera upaya pelatihan dan pembinaan agar desa memiliki produk unggulan. Produk unggulan desa dapat berbentuk destinasi wisata, olahan budidaya ikan, makanan kuliner, olahan atau oleh-oleh sebagai cikal bakal pengembangan kawsan wisata terpadu. Pembinaan dan pemberdayaan masyarakat dalam mengembangkan dan mengelola desa menjadi kawasan wisata terpadu membutuhkan perencanaan dan implementasi kebijakan secara terkoordinasi dengan pemerintah derah dalam menyediakan sarana dan prasarana pendukung, terutama sarana jalan sebagai transportasi utama.

Oleh karena itu, pengabdian kepada Masyarakat melalui program desa binaan ini memberikan beberapa rekomendasi sebagai bentuk evaluasi terhadap pemetaan potensi desa dan pelaksanaan pengabdian yang dilakukan. Rekomendasi ini disusun berdasarkan program jangka, pendek, menengah dan jangka panjang. Dalam jangka pendek, tim pengabdian merekomendasikan: pemerintah daerah Kabupaten Indragiri Hulu harus membuat akses jalan pintas menuju lokasi danau atau membuat jalan alternatif melalui desa/kelurahan lain; Menggerakkan masyarakat untuk melakukan penanaman pohon di pinggir danau untuk menjaga keindahan pohon yang masih alami sesuai habitat; membentuk dan memberikan pelatihan kelompok sadar wisata secara berkelanjutan; memberikan pelatihan pengelolaan Bumdes sebagai pengembang potensi tambak ikan dan kawasan wisata terpadu; dan memberikan pelatihan dan pemberdayaan masyarakat dengan mengembangkan olahan makanan dan oleh-oleh khas desa.

Dalam jangka menengah, tim memberikan rekomendasi: perlunya melakukan pembebasan lahan dipinggiran danau untuk penyiapan pengembangan kawasan wisata terpadu; pemerintah derah mulai menyiapkan infrastruktur pendukung dan fasilitas terkait seperti: listrik, MCK, dll; mengadakan sarena rekreasi dan hiburan seperti flying fox, jembatan gantung, dll; dan mengembangkan tanaman perkebunan dan pertanian yang sesuai dengan kondisi tanah. Sementara itu, untuk jangka panjang masyarakat dapat mengembangkan kawasan wisata terpadu baik agrowisata berbasis sawah, kebun buah-buahan, pertenakan dan ekowisata alam penangkaran buaya dan kelestarian tumbuhan hutan.

\section{UCAPAN TERIMA KASIH}

Pusat Studi Pariwisata dan Industri Kreatif (Puspaindra) melalui skema pengabdian desa binaan telah melakukan pengabdian kepada masyarakat program desa binaan. Artikel ini merupakan bagian dari rangkaian kegiatan awal pengabdian yang sangat dibutuhkan oleh masyarakat desa tersebut terutama dalam memanfaatkan potensi desa untuk meningkatkan ekonomi masyarakat. Oleh karena itu, tim pengabdian mengucapkan terimakasih kepada Ketua LPPM Universitas Riau yang sudah memberikan pendanaan kegiatan ini. Tim pengabdian juga mengucapkan terimakasih kepada Kepala Desa, aparatur desa dan pengelola Bumdes Desa Petalongan yang sudah menerima dengan baik dan memberikan kesempatan kepada Tim untuk melakukan pengabdian di desa ini.

\section{DAFTAR PUSTAKA}

Bagindo, M. P., Sanim, B., \& Saptono, T. 2016. Model Bisnis Ekowisata di Taman Nasional Laut Bunaken dengan Pendekatan Business Model Canvas. MANAJEMEN IKM: Jurnal Manajemen Pengembangan Industri Kecil Menengah, 11(1), 80-88. https://doi.org/10.29244/mikm.11.1.80-88

Bahri, B., \& Prasetyo, W. 2020. Pengentasan kemiskinan melalui pemberdayaan wirausaha dan program life skill untuk meningkatkan produktivitas kelompok UPPKS Kalipakem Baru. Riau Journal of Empowerment, 3(1), $27-37$. https://doi.org/10.31258/raje.3.1.27-37

Bakti, I., Sumartias, S., Damayanti, T., \& Nugraha, A. R. 2018. Pengembangan Model Komunikasi Pariwisata Berbasis Kearifan Lokal di Kawasan Geopark Pangandaran. Jurnal Kajian Komunikasi, 6(2), 217. https://doi.org/10.24198/jkk.v6i2.18459

Liu, C. H. S. 2018. Examining social capital, organizational learning and knowledge transfer in cultural and creative industries of practice. Tourism Management, 64, 258-270. https://doi.org/10.1016/j.tourman.2017.09.001

Lundberg, E. 2017. The importance of tourism impacts for different local resident groups: A case study of a Swedish seaside destination. Journal of Destination Marketing and Management, 6(1), 46-55. https://doi.org/10.1016/j.jdmm.2016.02.002 
Mulyadi, M., Pamukas, N. A., Adelina, A., Lukistyowati, I., \& Yoswati, D. 2019. Pelatihan budidaya ikan lele pada kolam terpal dengan sistem akuaponik di Desa Harapan, Kecamatan Sungai Apit, Kabupaten Siak, Provinsi Riau. Unri Conference Series: Community Engagement, 1, 347-354. https://doi.org/10.31258/unricsce.1.347354

Noor, M. Fa., \& Nala, I. W. L. 2020. Pariwisata dan Pelestarian Ekosistem Sungai; Desa Pela dalam Upaya Konservasi dan Peningkatan Ekonomi Masyarakat. Malang: Literasi Nusantara.

Qomar, N., Muhammad, A., Idwar, I., Sutikno, S., Isnaini, Z. L., Nawawi, A., \& Jhonnerie, R. 2019. Partisipasi anggota pokdarwis dalam program desa binaan untuk pengembangan ekowisata terintegrasi di Kampung Rawa Mekar Jaya Kecamatan Sungai Apit Kabupaten Siak. Unri Conference Series: Community Engagement, 1, 670-677. https://doi.org/10.31258/unricsce.1.670-677

Ridlwan, M. A., Muchsin, S., \& Hayat, H. 2017. Model Pengembangan Ekowisata dalam Upaya Pemberdayaan Masyarakat Lokal. Politik Indonesia: Indonesian Political Science Review, 2(2), 141. https://doi.org/10.15294/jpi.v2i2.9933

Yasir, Nurjanah, Salam, N. E., \& Yohana, N. 2019. Kebijakan komunikasi dalam membangun destinasi dan masyarakat sadar wisata di kabupaten bengkalis. Jurnal Studi Komunikasi (Indonesian Journal of Communications Studies), 3(November), 424-443. https://doi.org/10.25139/jsk.3i3.1548

Yasir, Y., Nurjanah, N., \& Yesicha, C. 2017. A Model of Communication to Empower Fisherman Community in Bengkalis Regency. MIMBAR, Jurnal Sosial Dan Pembangunan, 33(2), 226. https://doi.org/10.29313/mimbar.v33i2.2135

Zulfida, I., Fauzi, A., Rustiadi, E., \& Syaukat, Y. 2017. Kinerja Program Nasional Pemberdayaan Masyarakat Mandiri Perdesaan di Kabupaten Bandung. MIMBAR, Jurnal Sosial Dan Pembangunan, 31(2), 307. https://doi.org/10.29313/mimbar.v31i2.1362 